\title{
The Design of Application Architecture of the Institute of Business Based on Enterprise Architecture Planning
}

\author{
Muhammad Yusuf Morais ${ }^{1}$, Habibullah Akbar ${ }^{2}$
}

\begin{abstract}
Institute of Business (IOB) is committed to achieve its goals, i.e. becomes a place for economics and business as well as computer science developers, and prepare a ready-to-use Human Resources (HR), especially for Timor Leste. At present, IOB does not have an alignment between business processes and information systems owned. Therefore, this paper proposes an architectural design that bridges the alignment. The methods used to build the framework are include Enterprise Architecture Planning (EAP), SWOT, Value Chain, and Mc Farlan Grid. The built frameworks are focused on the needs of the application architecture. The resulted portfolio has 45 applications for various divisions of IOB. In addition, the SWOT analysis shows that IOB's internal and external factors are in the second quadrant. Thus, IOB's position is relatively strong, though it is facing a big challenge. The recommended strategy is the Strengths-Threats (ST) strategy that uses the company's strength to overcome the threats. This strategy includes improving facilities, adding faculties and departments, developing academic information systems, improving the quality of learning, and improving the human resources quality.
\end{abstract}

Keywords-- Enterprise Architecture Planning (EAP), Application Architecture, SWOT, Value Chain.

\section{INTRODUCTION}

The increasing need for the use of data and information in business functions that carried out by a higher education institution is a cause of the use of information systems for the university. This resulted in a large number of higher education institutions which are in the implementation information systems with the technology only considering current needs and the application of the information systems are overlapping each other. These conditions make the information systems are not be maximally utilized in accordance with what are expected based on the vision, mission, and objectives of the information systems application of the higher education institution, which are efficiency and effectiveness in fulfilling the universities' needs.

Institute of Business (IOB) is an institute engaged in the education sector in Timor-Leste, a country that recently became independent less than two decades ago. Currently, the IOB is one of the flagship universities in Timor Leste. However, the services provided to the IOB students are still carried out manually by using Microsoft Office. In addition, the existing applications still work independently, yet

\footnotetext{
${ }^{1}$ Magister of Informatics Engineering Study Program Bina Nusantara University Jalan Kebun Jeruk Raya No.27 Jakarta 11530 INDONESIA (e-mail: yusufmorais@gmail.com)

${ }^{2}$ Lecturer, BINUS University, Jln. Kebun Jeruk Raya No. 27 West Jakarta 11530 INDONESIA (phone: 021-5345830; fax: 0215300244; e-mail: habibrown@gmail.com)
}

integrated, therefore, a proper information architecture is required to integrate those various applications. The purpose of this paper is to create an application architecture with an enterprise architecture planning method that can be used as a foundation to develop a better information system.

\section{The Design of Application ARChitecture BASED ON ENTERPRISE ARCHITECTURE PLANNING}

Application architecture is a blueprint of behavior and interactions between applications enclosed in a business domain. There are several researches that have been carried out about application architecture.

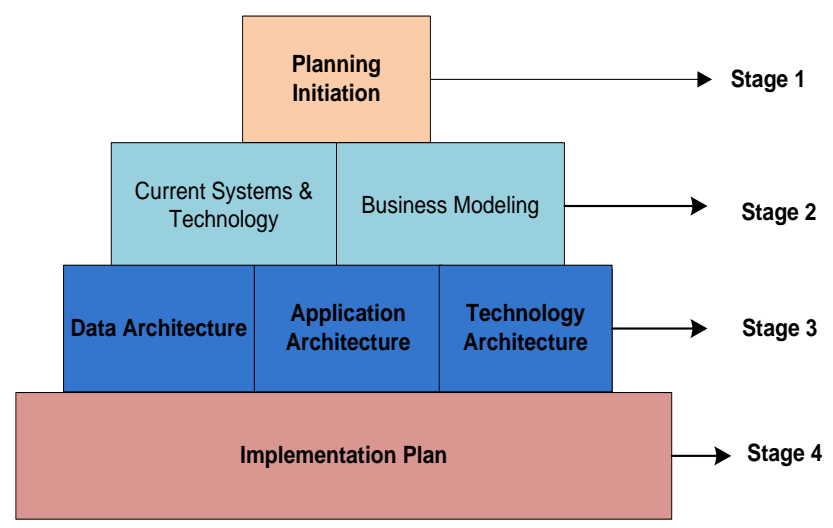

Fig. 1 EAP components.

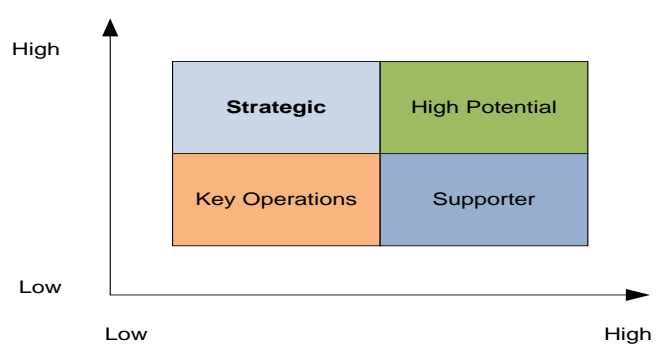

Fig. 2 Mc Farlan Grid.

A study titled "Information Technology Architecture Design in approach of Enterprise Architecture Planning" has resulted an overview of the blueprint about the information technology, i.e. data architecture, applications, and technology as the the guidelines of information technology needs [1].

Another study titled "Enterprise Architecture Planning Information systems, STMIK Bani Saleh with Zachmann Framework" aimed to use the Zachman Framework as a reference in formulating higher education institution needs in answering the challenge from stakeholders and as business strategy [2]. Integrated information can be arranged in development and implementation plan of various necessary 
applications so that the data integration and deployment flow is more organized in accordance with the information systems management. With a more organized output, it is hoped that the information presented to all stakeholders and decision makers in the Bani Saleh are more accurate and fast.

This paper is different with the previous research in the use of Enterprise Architecture Planning (EAP) method and the SWOT analysis in providing business strategy recommendations of the organization which have not been used in the previous researches. Therefore, this paper emphasizes on the EAP methods and SWOT analysis.

EAP is a method used to build an information architecture. It is an approach created by Steven H. Spewak to build enterprise architecture based on business and data impulses. EAP is the process of defining architectures in the use of information to support of the business and plan for implementing those architectures [3]. Fig. 1 shows EAP components.

1) Value Chain: Every activity of the value chain is a brick to build competitive advantage. One artifact of architecture vision is the value chain diagram describing the company's goals that can be seen from primary and supporting activities [4].
2) Mc Farlan Grid: Mc Farlan Strategic Grid aims to analyze an application or information system in an operational organization/company based on current conditions, planned conditions, and applications that are considered potential in supporting the business, thus facilitating the operations of management to make decisions in determining the position of the organization/company operational IS/IT as well as the organization/company operational requirements in determining the direction of IS/IT will be fulfilled, which of course is adjusted to the capabilities and vision and mission of the organization/company operations in the future [5]. Fig. 2 shows Mc Farlan Grid.

3) SWOT Analysis: SWOT Analysis is the identification of various factors that systematically exist to formulate company's strategy. This analysis is based on logic that can maximize the strengths and opportunities, yet at the same time can minimize weaknesses and threats [6].

\section{MEthodOLOGY}

The research in this paper refers to the EAP methodology. The research framework in this study is shown in Fig. 3.

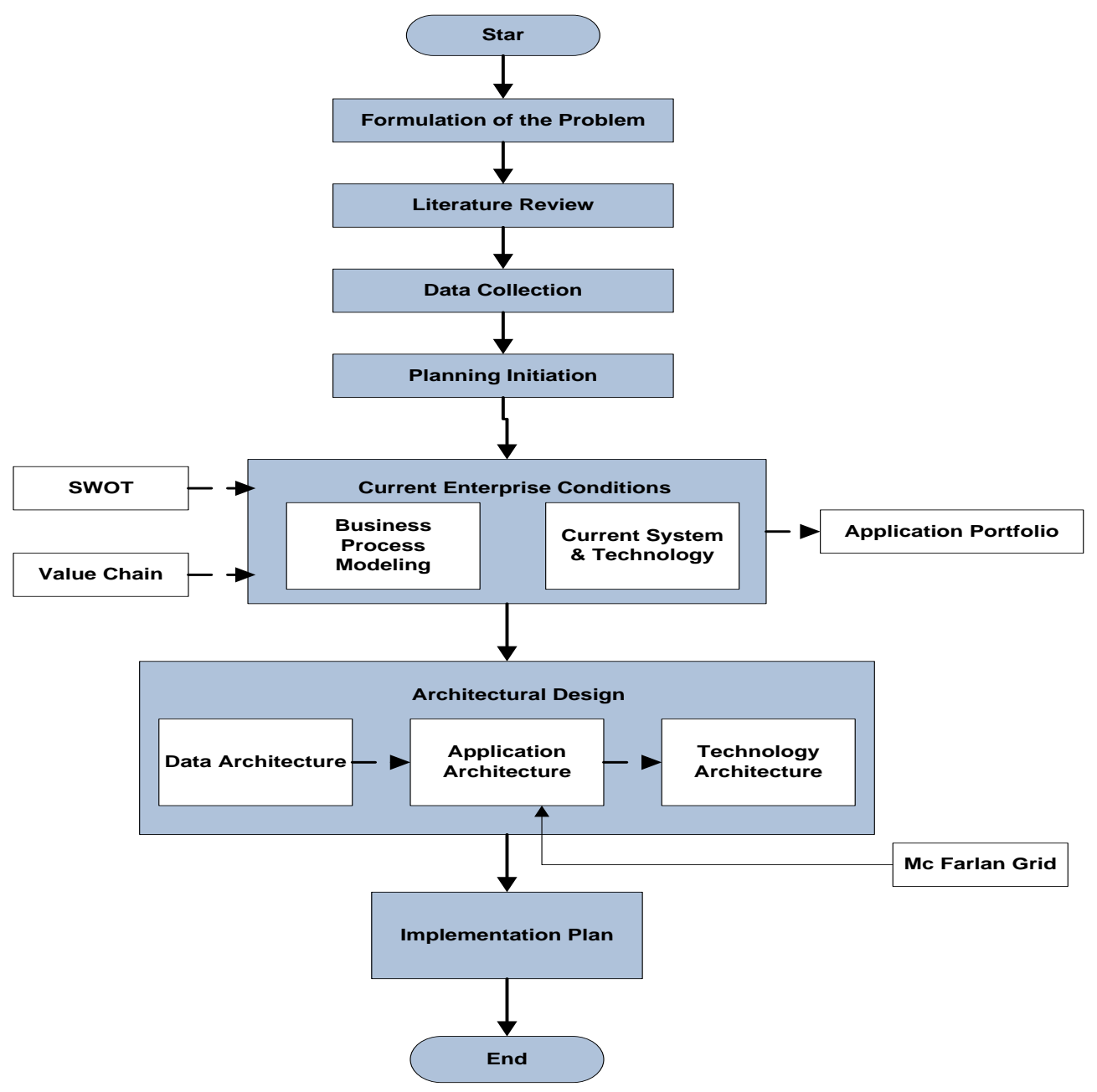

Fig. 3 Research stages. 


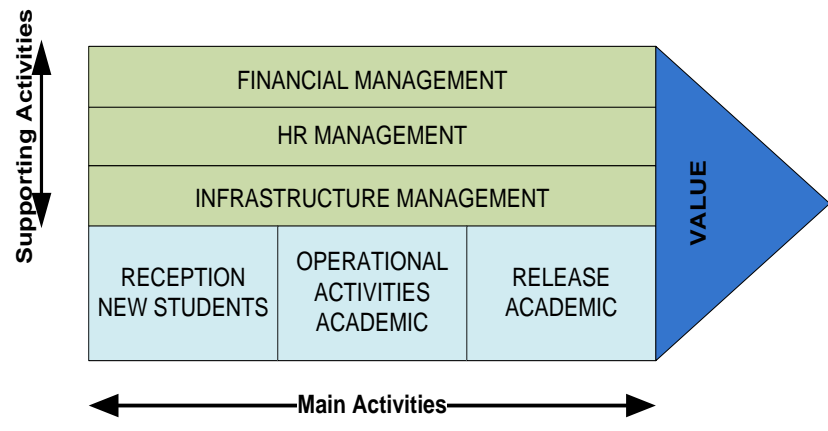

Fig. 4 IOB value chain.

TABLE I

NEW STUdENT ADMissions ApplicATION (PMB)

\begin{tabular}{|l|l|}
\hline Name & $\begin{array}{l}\text { New Student Admission Application } \\
\text { (PMB) }\end{array}$ \\
\hline Description & $\begin{array}{l}\text { New student admissions application is } \\
\text { a system that serves as the facilities for } \\
\text { the registration of new students } \\
\text { candidate. }\end{array}$ \\
\hline $\begin{array}{l}\text { The Unit } \\
\text { Manager/User }\end{array}$ & Admission Committee \\
\hline Business Process & Admission \\
\hline Usage Type & Offline \\
\hline Implementation year & 2010 \\
\hline Base Technologies & Windows 7, Office 2007 \\
\hline
\end{tabular}

Based on the research stages in Fig. 3, the stages in this research preparation are the problem formulation identification, library study (library research), data collection, planning initialization, the current enterprise conditions including business process modeling as well as current systems and technology, architecture design including the data architecture, application and technology architecture, and the last is the implementation plan.

The methods used to obtain data were the survey and the questionnaire methods. The survey methods require contacts or connections between the researcher and research subject (respondent) to obtain required data, while the questionnaire method gives the responsibility to the respondents to read and answer the questions provided by researcher.

\section{RESUltS AND DisCUSSION}

The business modelling processes was done by identifying and documenting the organizational structure and identifying and defining business functions by making business models using value chain. The business functions identification based on EAP methodology was carried out by defining the business area using the value chain model in creating enterprise business model. The value chain was created to identify and define business areas by classifying the areas into primary business (primary activities) and supporting business (support activities) in the enterprise. Therefore, there are three business processes in the primary business, i.e. financial management, human resource management, and infrastructure management. While supporting business have three business processes, i.e. new student admissions, academic operational activities, and academic release. IOB value chain is shown in Fig. 4.
TABLE II

ACADEMIC APPLICATION

\begin{tabular}{|l|l|}
\hline Name & Academic Application \\
\hline Description & $\begin{array}{l}\text { Academic Application is a system } \\
\text { functioning as a facility to manage } \\
\text { student score and the study planning } \\
\text { (Study Planning Card) guidance } \\
\text { process. }\end{array}$ \\
\hline Unit Manager/User & Academic \\
\hline Business Process & Academic \\
\hline Type of Use & Offline \\
\hline Implementation Year & 2010 \\
\hline Technology Base & Windows 7, Office 2007 \\
\hline
\end{tabular}

TABLE III

RESULTS OF IFAS QUESTIONNAIRE

\begin{tabular}{|c|c|c|c|c|}
\hline No & Internal Strategic Factors & Value & Rate & Score \\
\hline \multicolumn{5}{|c|}{ Strength } \\
\hline 1. & $\begin{array}{l}\text { The facilities availability such } \\
\text { as computers, cars, buildings } \\
\text { and other infrastructure. }\end{array}$ & 0.153 & 4 & 0.612 \\
\hline 2. & $\begin{array}{l}\text { Support from Rectorate to the } \\
\text { development of the IT field. }\end{array}$ & 0.153 & 4 & 0.612 \\
\hline 3. & $\begin{array}{l}\text { The Rectorate support in } \\
\text { improving human resources } \\
\text { (HR). }\end{array}$ & 0.153 & 4 & 0.612 \\
\hline 4. & $\begin{array}{l}\text { Obtain an achievement as an } \\
\text { A accredited college. }\end{array}$ & 0.153 & 4 & 0.612 \\
\hline \multicolumn{4}{|c|}{ Total Strength } & 2.448 \\
\hline \multicolumn{5}{|c|}{ Weakness } \\
\hline 1. & $\begin{array}{l}\text { The existing application units } \\
\text { are still independent so it is } \\
\text { difficult to exchange data. }\end{array}$ & 0.131 & 3 & 0.393 \\
\hline 2. & $\begin{array}{l}\text { There is no integrated system } \\
\text { that capable of processing } \\
\text { students' data and activities, } \\
\text { as well as lecturer data. }\end{array}$ & 0.125 & 3 & 0.375 \\
\hline 3. & Inadequate human resources. & 0.131 & 3 & 0.393 \\
\hline \multicolumn{4}{|c|}{ Total Weakness } & 1.161 \\
\hline
\end{tabular}

Each of the main activities can be described as follows. New Student Admissions can be described as an activity that covers the process of admitting new students to the data collection of new students. Academic operations are the activity related to the business of running the operations of academic or teaching and learning activities for students as long as the students are in the academic period. Academic release are activities related to the management of the final academic or academic release as the ending of the study.

The supporting activities can be explained as follows. Human Resource Management is a supporting activity for the determination of needs, monitoring, and allocation of human resources, especially in academic operational activities, Financial Management is a supporting activity related to business providing financial management support that revolves around development budget and investment planning, Infrastructure Management is a supporting activity that starts from planning the needs of facilities and equipment and management for academic activities, including the management of the IC Center. 
TABLE IV

RESULTS OF EFAS QUESTIONNAIRE

\begin{tabular}{|c|l|c|c|c|}
\hline No & \multicolumn{1}{|c|}{ Internal Strategic Factors } & Value & Rate & Score \\
\hline 1. & $\begin{array}{l}\text { IOB opens opportunities for } \\
\text { lecturers with standards and } \\
\text { good quality in achieving } \\
\text { further education } \\
\text { scholarships. }\end{array}$ & 0.142 & 4 & 0.568 \\
\hline 2. & $\begin{array}{l}\text { IOB is in cooperation with } \\
\text { partners within Timor Leste } \\
\text { as well as abroad, so that IOB } \\
\text { will be known nationally and } \\
\text { internationally. }\end{array}$ & 0.148 & 4 & 0.592 \\
\hline 3. & $\begin{array}{l}\text { IOB is competitively } \\
\text { competing with state } \\
\text { universities and other big } \\
\text { private universities. }\end{array}$ & 0.148 & 4 & 0.592 \\
\hline \multicolumn{4}{|c|}{ Total Opportunities } \\
\hline 1. & $\begin{array}{l}\text { The increasing number of } \\
\text { students year by year causes } \\
\text { the need of information } \\
\text { technology support to be } \\
\text { taken into account. }\end{array}$ & 0.148 & 4 & 0.592 \\
\hline 2. & $\begin{array}{l}\text { Faculties and study programs } \\
\text { at other universities that vary. }\end{array}$ & 0.137 & 4 & 0.548 \\
\hline 3. & $\begin{array}{l}\text { Systems and information } \\
\text { technology used by other } \\
\text { universities. }\end{array}$ & 0.137 & 4 & 0.548 \\
\hline 4. & $\begin{array}{l}\text { The educational level of } \\
\text { teaching staff at other } \\
\text { universities. }\end{array}$ & 0.137 & 4 & 0.548 \\
\hline \multicolumn{5}{|c|}{ Total Threats } \\
\hline
\end{tabular}

The next stage of the current enterprise condition review is the observation of the systems and technologies used by enterprises at the time by documenting the basis of systems and technologies that are being used by enterprises. The documentation product is referred as a catalogue of information resources (Information Resource Catalogue or IRC).

TABLE V

THE COMPARISON OF IFAS AND EFAS

\begin{tabular}{|l|l|}
\hline \multicolumn{1}{|c|}{ X Point Internal } & \multicolumn{1}{c|}{ Y Point External } \\
\hline Strength - Weakness & Opportunities - Threats \\
$=2.448-1.161$ & $=1.572-2.236$ \\
$=1.287$ & $=-0.664$ \\
\hline
\end{tabular}

IRC in Table I describes the applications and technologies used by IOB currently, especially in the New Student Admission (NSA) business process. From the table, the description of the application for new student admissions can be inferred as $\mathrm{s}$ system that functions as a facility for registering new student candidates, the management unit is the new student admission committee, business processes called new student admissions, offline type of use, the implementation year is 2010, and the technology base is in the form of Windows 7 and Office 2007

The IRC on Table II explains the application and the technology currently used by the IOB, especially on the business processes of academic operations. From the table above, it can be seen that the description of the academic application is a system that functions as a facility to manage student values and the study planning card (KRS) guidance process, the management unit is the academic affair section, business processes is called academic, the type of use is offline, the implementation year is 2010, and the technology base is Windows 7 and Office 2007.

The result of IFAS and EFAS questionnaire are shown in Table III and Table IV, then the comparation between the two is shown in Table V. From Table V it can be seen that the IFAS value that given the $\mathrm{X}$ coordinate values 1.287 , which was obtained by the strength minus the weakness, while the EFAS value that given the Y coordinate values -0.664 , which is obtained by the formula of opportunity minus the threat.

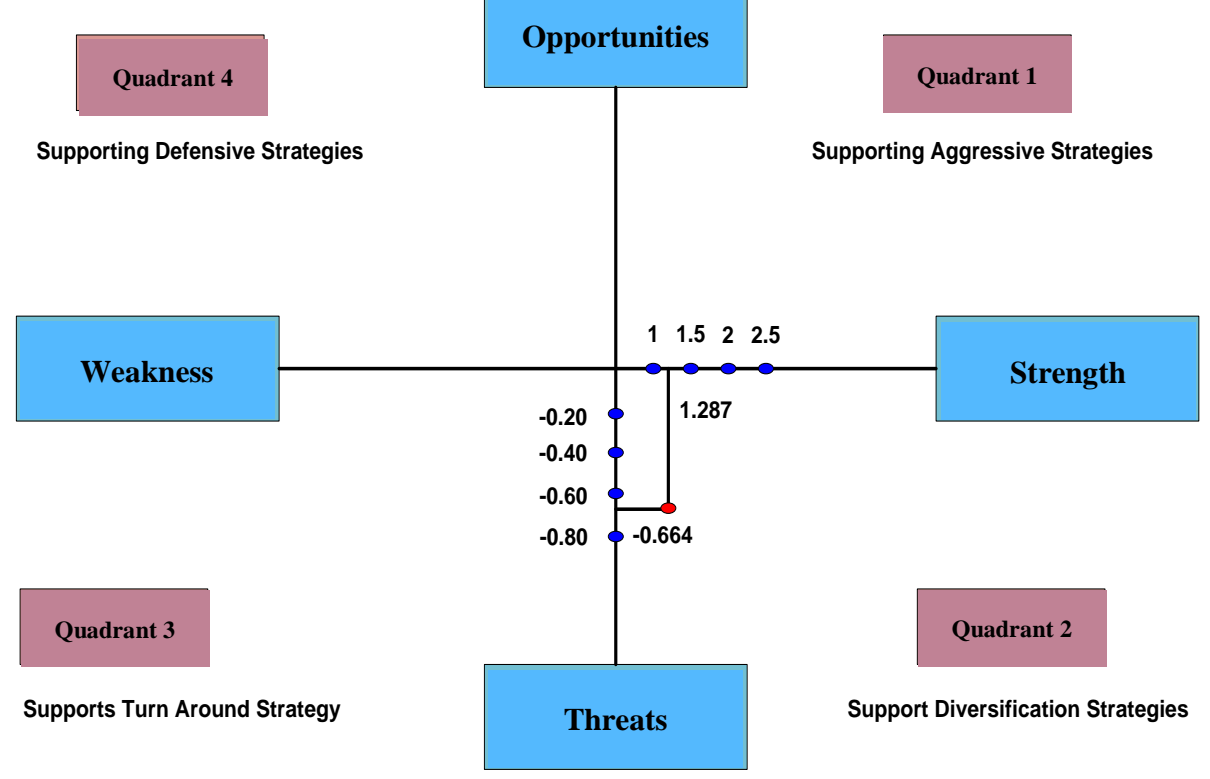

Fig. 5 SWOT diagram of comparison of IFAS and EFAS. 
TABLE VI

DATA ENTITY CANDIDATE

\begin{tabular}{|c|c|c|c|}
\hline \multirow{7}{*}{\begin{tabular}{|l|} 
No \\
1.
\end{tabular}} & \multirow{7}{*}{\begin{tabular}{|l} 
Business Entity \\
New Student \\
Admission \\
(PMB) Entity
\end{tabular}} & \multicolumn{2}{|r|}{ Data Entity } \\
\hline & & 1. & Student candidates registration entity \\
\hline & & 2. & Registration payment Entity \\
\hline & & 3. & $\begin{array}{l}\text { Student admission entrance exam } \\
\text { Schedule-Management entity }\end{array}$ \\
\hline & & 4. & $\begin{array}{l}\text { Student admission entrance exam } \\
\text { entity }\end{array}$ \\
\hline & & 5. & Students registration entity \\
\hline & & 6. & Students admission reports entity \\
\hline \multirow[t]{17}{*}{2.} & \multirow{17}{*}{$\begin{array}{l}\text { Academic } \\
\text { Operational } \\
\text { Entity }\end{array}$} & 1. & Student re-registration entity \\
\hline & & 2. & Study Planning (KRS) Entity \\
\hline & & 3. & Classes Scheduling Entity \\
\hline & & 4. & Study Planning Changing Entity \\
\hline & & 5. & Supervision Entity \\
\hline & & 6. & Exam Scheduling Entity \\
\hline & & 7. & Score Entity \\
\hline & & 8. & Curriculum Management Entity \\
\hline & & 9. & Academic Calendar Entity \\
\hline & & 10. & Scientific Writing Entity \\
\hline & & 11. & Study Result Entity \\
\hline & & 12. & Field Practice Entity \\
\hline & & 13. & Thesis Guidance Entity \\
\hline & & 14 & Academic Absence Entity \\
\hline & & 15. & Transfer Administration Entity \\
\hline & & 16. & Academic Reporting Entity \\
\hline & & 17. & Thesis Entity \\
\hline \multirow[t]{7}{*}{3.} & \multirow{7}{*}{$\begin{array}{l}\text { Academic } \\
\text { Release Entity }\end{array}$} & 1. & Graduation Entity \\
\hline & & 2. & Alumni Entity \\
\hline & & 3. & Reports Entity \\
\hline & & 4. & Diploma Entity \\
\hline & & 5. & Transcripts Entity \\
\hline & & 6. & Drop Out Administration Entity \\
\hline & & 7. & Resignation Administration Entity \\
\hline \multirow[t]{6}{*}{4.} & \multirow{6}{*}{$\begin{array}{l}\text { Financial } \\
\text { Management } \\
\text { Entity }\end{array}$} & 1. & Lecturer Salary Entity \\
\hline & & 2. & Education Cost Entity \\
\hline & & 3. & Reports Entity \\
\hline & & 4. & Debt Accounting Entity \\
\hline & & 5. & Financial Accounting Entity \\
\hline & & 6. & Budgeting Entity \\
\hline \multirow[t]{5}{*}{5.} & \multirow{5}{*}{\begin{tabular}{|l|} 
Human \\
Resources \\
Management \\
Entity
\end{tabular}} & 1. & Personnel Management Entity \\
\hline & & 2. & Absence Reports Entity \\
\hline & & 3. & Recruitment Entity \\
\hline & & 4. & Training \& Education Entity \\
\hline & & 5. & Reports Entity \\
\hline \multirow[t]{4}{*}{6.} & \multirow{4}{*}{$\begin{array}{l}\text { Infrastructure } \\
\text { Management } \\
\text { Entity }\end{array}$} & 1. & Procurement Entity \\
\hline & & 2. & Ordering Entity \\
\hline & & 3. & Asset Management Entity \\
\hline & & 4. & Reports Entity \\
\hline
\end{tabular}

As a result, the SWOT diagram that can be generated from the IFAS and EFAS comparison table can be seen as in Fig. 5.

Based on the SWOT analysis, IOB's internal and external factors are in the second quadrant position. This quadrant indicates that the IOB position is strong, however it faces a big threat or challenge. The strategy recommendation is the Diversification strategy, it means that the IOB is in steady state yet facing a number of threats or tough challenges so that it is estimated the organization wheel will have difficulty to continue running when its only rely on the previous strategies Therefore, the strategy that can be applied is the StrengthsThreats (ST) strategy. The ST strategies are:

a. improve the facilities and add faculties and departments;

b. create academic information systems; and

c. improve the quality of learning and the quality of human resources.

TABLE VII

LIST OF APPLICATION PORTFOLIO

\begin{tabular}{|c|c|}
\hline Strategic & High potential \\
\hline $\begin{array}{l}\text { - Matriculant registration system } \\
\text { - Registration payment system } \\
\text { - Matriculant Entrance } \\
\text { examination schedule } \\
\text { management system } \\
\text { - Matriculant Entrance } \\
\text { Examination Systems } \\
\text { - Student registration system } \\
\text { - Matriculant admission reports } \\
\text { Systems }\end{array}$ & $\begin{array}{l}\text { - } \text { Graduation System } \\
\text { - } \text { Alumni System } \\
\text { - } \text { Reporting System } \\
\text { - } \text { Diploma System } \\
\text { - } \text { Transcript System } \\
\text { - } \text { Drop Out Administration } \\
\text { - System } \\
\text { - } \text { Resignation system } \\
\text { - Procurement System } \\
\text { - } \text { Ordering systems } \\
\text { - } \text { Reporting System }\end{array}$ \\
\hline $\begin{array}{r}\text { Opera } \\
\text { Ke }\end{array}$ & Supports \\
\hline $\begin{array}{l}\text { - Student re-registration system } \\
\text { - Study Planning System } \\
\text { - Lecture Scheduling System } \\
\text { - Study plan changing system } \\
\text { - Supervision System } \\
\text { - Exam scheduling system } \\
\text { - Scoring System } \\
\text { - } \text { Curriculum Management System } \\
\text { - Academic Calendar system } \\
\text { - Scientific writing system } \\
\text { - Study Result system } \\
\text { - Field Practice System } \\
\text { - Thesis Counselling System } \\
\text { - Academic Absence System } \\
\text { - Transfer Administration System } \\
\text { - Academic Reporting System } \\
\text { - Thesis System }\end{array}$ & $\begin{array}{l}\text { - Lecturer Salary systems } \\
\text { - Education Cost Systems } \\
\text { - Reporting System } \\
\text { - Debt Accounting System } \\
\text { - Financial Accounting } \\
\text { - System } \\
\text { - Budgeting System } \\
\text { - Personnel Management } \\
\text { - System } \\
\text { - Recruitment System } \\
\text { - Training \& Education } \\
\text { System } \\
\text { - Reporting System }\end{array}$ \\
\hline
\end{tabular}

Data architecture must be able to identify the data that supports business functions as defined in the business model. To define the data architecture, firstly, the candidate of data entity was registered by brainstorming to people, places, and events that have significances (information) related to the business model of higher education. Data entity candidate is shown in Table VI.

The goal of this Relation Attribute stage was defining and describing the standards regarding each of the entities contained in the data architecture as well as providing graphic illustration about the interrelation in between. To model the relationships between data entities, the illustration used the E$\mathrm{R}$ diagram.

Fig. 6 explains that the relations between data entities with the relations between the used and budgeted are many to one, used with student admission (PMB) committee are many to one, student admission (PMB) committee with the test is one to one, the test with the selection schedule is many to one, and the exam with the test results is many to one. 


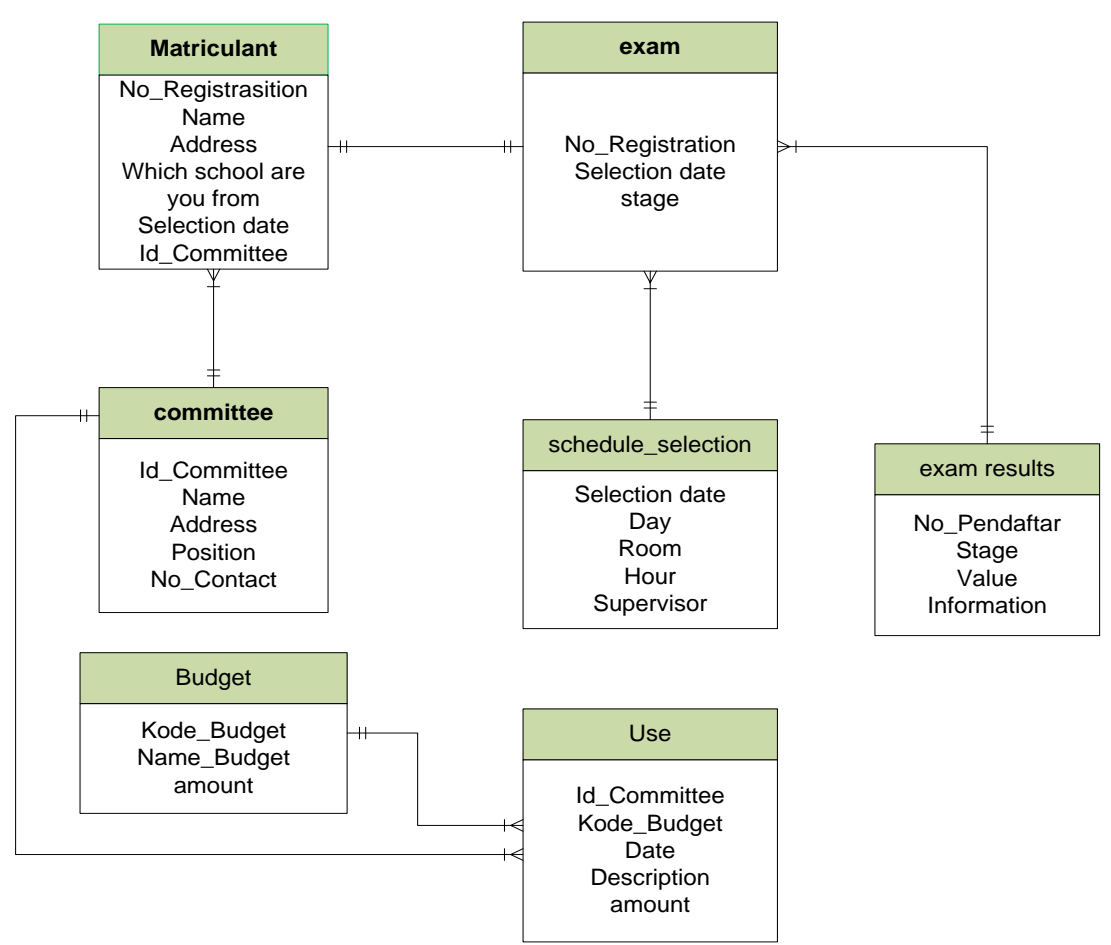

Fig. 6 ER-Diagram of Student Admission.

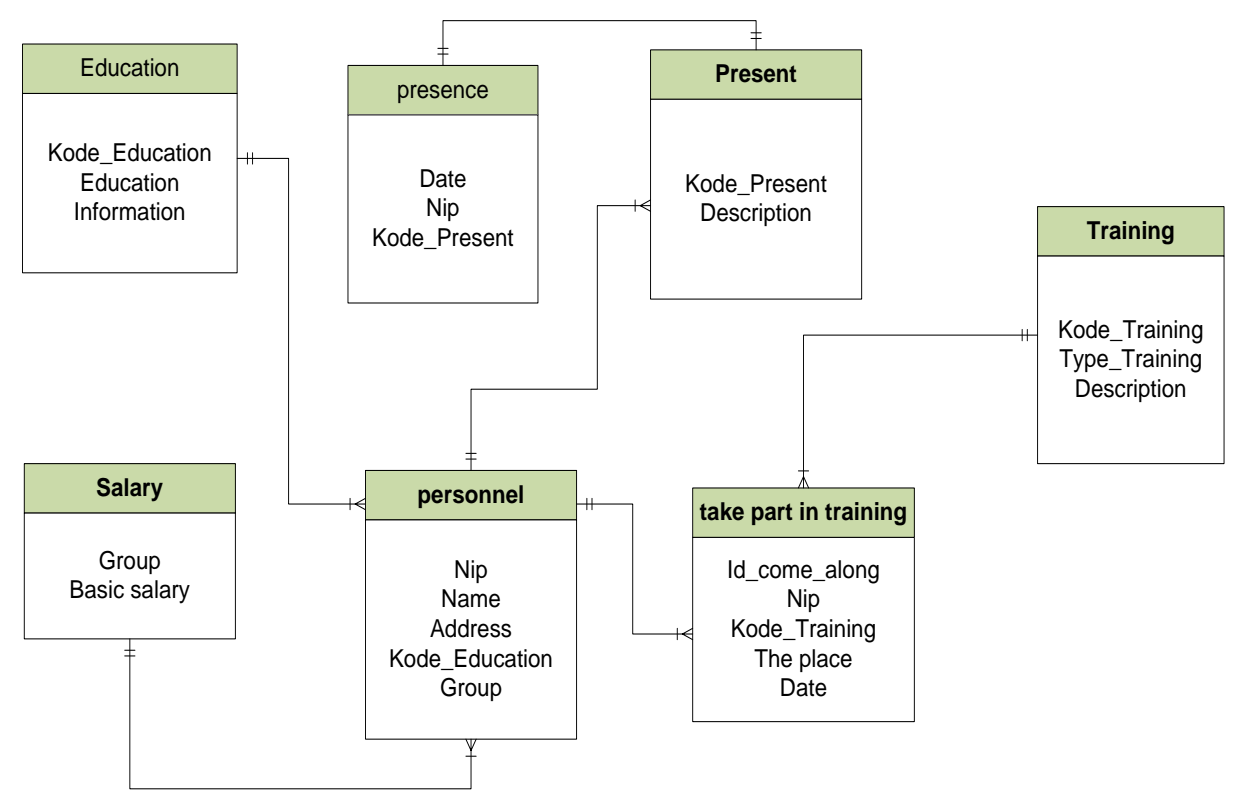

Fig. 7 ER-Diagram of human resource management.

Fig. 7 explains the relation between data entities, with the partnership between training with the training participation is one to many, participation with personnel training is many to one, personnel salary is many to one, personnel education is many to one personnel with the presence is one to many, and personnel presence with the presence is one to one.

After obtaining the possible applications to be developed in every unit on the IOB, the next step was to determine the quadrant of each application based on a Mc Farlan portfolio.
The process of determining portfolio quadrants can be formulated as in Table VII.

This stage of technology architecture aimed to define the technology platform needed to provide an application environment that manages data and supports business functions The purpose of this technology architecture was based on the application architecture needs that have been made, i.e. describing the management of enterprise architecture. 
TABLE VIII

IMPLEMENTATION PLAN

\begin{tabular}{|c|c|}
\hline System Implementation & $\begin{array}{c}\text { Time } \\
\text { (Months) }\end{array}$ \\
\hline Matriculant registration system & \multirow{6}{*}{6} \\
\hline Registration payment system & \\
\hline $\begin{array}{l}\text { Matriculant Entrance examination schedule } \\
\text { management system }\end{array}$ & \\
\hline Matriculant Entrance Examination Systems & \\
\hline Student registration system & \\
\hline Matriculant admission reports Systems & \\
\hline Student re-registration system & \multirow{17}{*}{8} \\
\hline Study Planning System & \\
\hline Lecture Scheduling System & \\
\hline Study Planning Changing Entity & \\
\hline Supervision System & \\
\hline Exam scheduling system & \\
\hline Scoring System & \\
\hline Curriculum Management System & \\
\hline Academic Calendar system & \\
\hline Scientific writing system & \\
\hline Study Result system & \\
\hline Field Practice System & \\
\hline Thesis Counselling System & \\
\hline Academic Absence System & \\
\hline Transfer Administration System & \\
\hline Thesis System & \\
\hline Academic Reporting System & \\
\hline Lecturer Salary systems & \multirow{11}{*}{6} \\
\hline Education Cost Systems & \\
\hline Debt Accounting System & \\
\hline Financial Accounting System & \\
\hline Financial Reporting System & \\
\hline Budgeting System & \\
\hline Personnel Management System & \\
\hline Absence Reports System & \\
\hline Recruitment System & \\
\hline Training \& Education System & \\
\hline Human Resources Management System & \\
\hline Graduation System & \multirow{10}{*}{4} \\
\hline Alumni System & \\
\hline Reporting System & \\
\hline Diploma System & \\
\hline Transcript System & \\
\hline Drop Out Administration System & \\
\hline Resignation system & \\
\hline Procurement System & \\
\hline Ordering systems & \\
\hline Asset management system & \\
\hline
\end{tabular}

In the Fig. 8 there are B and C campus, because these B and $\mathrm{C}$ campus operate the academic activity at the college level. The IT Centre is on the $\mathrm{C}$ campus. Besides that, since the Faculty of Information Communication and Technology (ICT) is on the $\mathrm{C}$ campus, therefore there is information system centre on the $\mathrm{C}$ campus. Thus, the process of network mapping started from the campus C. From the picture, it can be explained as follows. Internet Service Provider (ISP) providing internet services, but installed a firewall for security. Then, the firewall is connected to the modem and modem is connected to the Router, the Router is then connected to the Switch, the Switch is then connected to the Hub in each unit. All of these components are in the management section of the IT Centre in the Infrastructure unit. From the Switch, it is connected to the ICT Faculty and the head of department. There is also connection from the Switch which is connected to $1,2,3$ and 4 laboratories. Thus, each section can access the internet from an existing Hub.

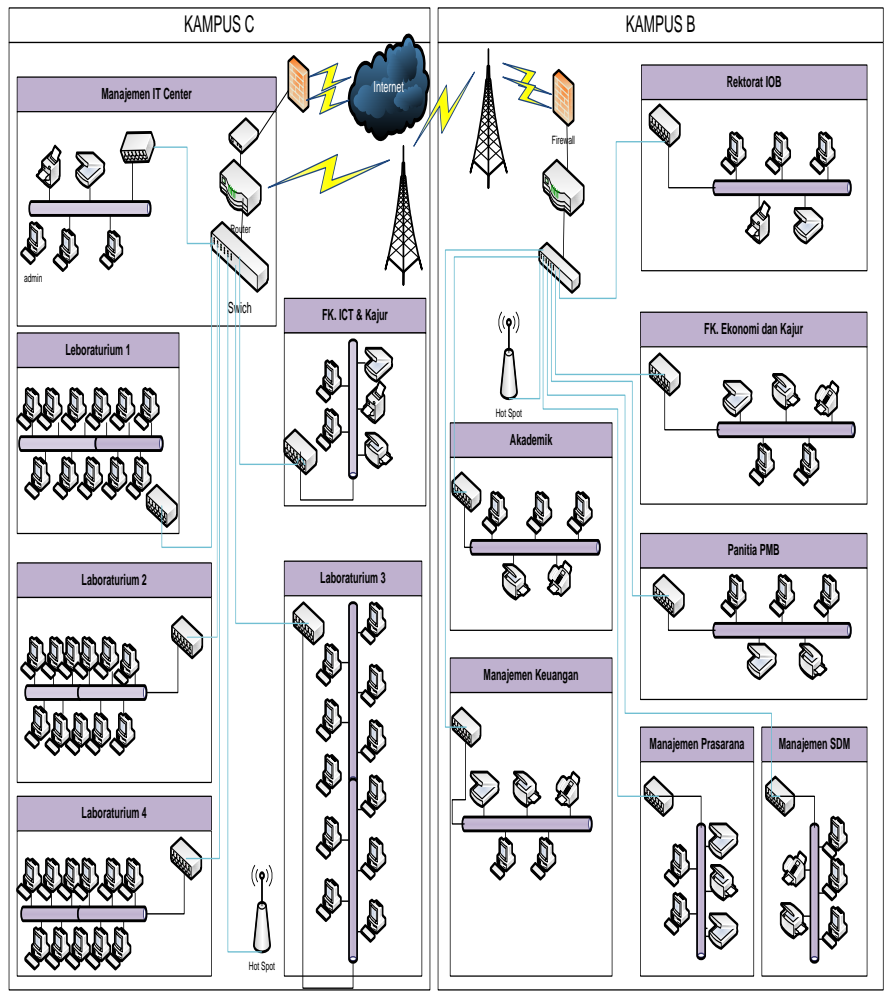

Fig. 8 Network architecture scheme.

Then, the $\mathrm{C}$ campus sends internet network to B campus by the use of radio tower. The $\mathrm{B}$ campus receiving internet communication from campus $\mathrm{C}$ with the radio tower. Then, the radio tower is connected to the firewall as a security system and the connection is forwarded to Router, Switch, and Hub. Thus, each unit can access the internet through the existing Hub. The units at B campus are the IOB Rector, the Faculty of Economics along with their head of departments, Student Admissions committee, infrastructure management, HR management, financial management, and academic.

This implementation plan stage was the stage of the application implementation, as shown in Table VIII.

In Table VIII it can be seen that the first stage in making the system was the matriculant registration system, registration payment system, student admission exam schedule management system, student Admission examination system, student registration system, and student admission reporting system. The second stage is the student reregistration system, study planning system, lecture scheduling system, study planning changing system, supervision system, exam scheduling system, scoring system, curriculum 
management system, academic calendar system, scientific writing system, study result system, field practice system, thesis counselling system, academic absence system, transfer administration system, thesis system, and academic reporting system. The third stage included lecturer salary system, education cost systems, debt accounting systems, financial accounting systems, financial reporting systems, budget systems, personnel management systems, absence report systems, recruitment systems, training and education systems, and HR management reporting systems. The fourth stage included the graduation system, alumni system, reporting system, diploma system, transcript system, drop out administration system, resignation system, procurement system, ordering system, asset management system, and infrastructure reporting system. The required time in the system design and implementation for the first stage took six months, the second stage was eight months, the third stage was six months, and for the fourth stage was four months.

\section{CONCLUSIONS AND SUGGESTIONS}

This paper has produced a design application architecture for IOB in Timor Leste. Business entities that have been identified are the main activities (admissions, academic, operational and academic release) and the supporting activities (financial management, infrastructure management, and human resource management). The resulting application portfolio identifies that there are 45 information systems that need to be implemented.

Moreover, the SWOT analysis shows that IOB is in the second quadrant position, which signifies a strong position but faces major challenges. The strategies that can be applied are improving facilities, adding faculties, departments, developing academic information systems, improving the quality of learning, and improving the quality of human resources.

However, the development of information systems should be administered by providing socialization to every organizational unit. Application development is suggested to be administered in stages and in accordance with the planned implementation sequence that has been developed and built using open source software to reduce costs.

\section{REFERENCES}

[1] T. Suryana, "Perancangan Arsitektur Teknologi Informasi dengan Pendekatan Enterprise Architecture Planning,” Maj. Ilm. UNIKOM, Vol. 10, No. 2, pp. 223-236, 2014.

[2] H.K. Bharata, Sulistiyowati, and S. Hanadwiputra, "Enterprise Architecture Planning Sistem Informasi STMIK Bani Saleh dengan Zachmann Framework,” J. Gerbang, Vol. 8, No. 1, pp. 80-88, 2018.

[3] S. Aswati, S. Malawat, Suhendra, and K. Anwar, "Enterprise Architecture Planning dalam Pengembangan Sistem Informasi Perguruan Tinggi,” J. Sist. Inf., Vol. 2, No. 11, pp. 1-8, 2017.

[4] S. Herman, A.A.N. Fajrillah, and R. Andreswari, "Perancangan Enterprise Architecture pada Fungsi Rekam Medis Rumah Sakit dengan Pendekatan Togaf ADM,” J. Rekayasa Sist. Ind., Vol. 4, No. 1, pp. 37-46, 2017.

[5] Y. Septiana, "Perencanaan Strategis Sistem Informasi dengan Pendekatan Ward and Peppard Model (Studi Kasus: Klinik INTI Garut),” J. Wawasan Ilm., Vol. 8, No. 1, pp. 8-24, 2017.

[6] A.D. Riyanto, A. Rosidi, and Suparmono, "Perencanaan Sistem Informasi Strategis pada AMIK BSI Purwokerto,” J. Teknol. Inf., Vol. 8, No. 11, pp. 144-166, 2013. 